Article

\title{
Groundwater Governance in the Azores Archipelago (Portugal): Valuing and Protecting a Strategic Resource in Small Islands
}

\author{
J. Virgílio Cruz * (i) and Nuno Soares \\ IVAR - Research Institute for Volcanology and Risk Assessment and Department of Geosciences, \\ Faculty of Sciences and Technology, University of the Azores, 9500-321 Ponta Delgada, Portugal; \\ nanysoares@hotmail.com \\ * Correspondence: jose.vm.cruz@uac.pt; Tel.: +351-296-650-147; Fax: +351-296-650-142
}

Received: 24 January 2018; Accepted: 26 March 2018; Published: 31 March 2018

\begin{abstract}
Studies on groundwater governance status at EU national and river basin district levels are rare, hindering lessons learned at each administrative scale to be shared. Groundwater is a common-pool resource of strategic significance in the Azores archipelago (Portugal), thus calling for sustainable development. Groundwater governance emerged in the last decades as a path to sustainable resources management, and the present paper characterizes the current status of governance in the Azores, where management is pursued according to a vertically-integrated system. A survey made among 43 specialists showed that despite the instrumental role of groundwater for water supply there is a need to increase awareness on groundwater valuing and protection. The application of benchmark criteria to evaluate the groundwater governance state-of-art shows that technical capacities are diminishing governance effectiveness due to the lack of quantitative data, and further enforcing of the groundwater legal framework to the specificities of the Azores is needed. The empowerment of the government agency being responsible for the groundwater management is also envisaged. The failure to account for the economic dimension of the groundwater governance, the insufficient development of cross-sectorial approaches, and the unsuccessful public participation are other weaknesses on the groundwater governance in the Azores.
\end{abstract}

Keywords: groundwater; governance; water management; water planning; Azores

\section{Introduction}

Groundwater is a common-pool resource of global significance, therefore vulnerable to unconstrained exploration by individuals without consideration of broader community interests [1-3]. Groundwater development can lead to several environmental and socioeconomic impacts, such as unsustainable abstraction, social inequity with regards to access to water, land subsidence, saline intrusion and other quality problems, degradation of water-dependent ecosystems, or surface-dependent water bodies or diminishing of drought resilience [4,5]. Due to global unsustainable development, groundwater depletion has been characterized in major regions worldwide, from Africa to Asia, America or Australia [6], or in regional studies [7,8], stressing the need of a conservative approach [9].

The opportunity and advantages of the sustainable development of groundwater resources has been illustrated in several case studies [10-14], often pushed by policy developments [15-17]. Nevertheless, management gaps are often observed, leading to the need of taking into account the effectiveness of measures taken [18], and besides the lack of knowledge, ineffectiveness drivers are explained by inadequate government structure $[1,19]$. Thus, groundwater governance emerged in 
the last decades as a path to sustainable resource management through the consideration of diverse interests, from both public and private sectors, as well as from citizens. The relationship between stakeholders is mediated in the context of a pool of laws and regulations, through the intermediation of mechanisms, processes, and institutions [1,20,21]. A comprehensive study developed by a set of international institutions proposed a definition of groundwater governance as a process that promotes responsible collective actions taken in order to ensure control, protection, and sustainable use of groundwater resources and aquifer systems, thus enhancing benefits for both humankind and ecosystems [22].

Groundwater governance comprises both the framework and the principles to achieve a collective and sustainable groundwater management, observing equity as well as efficiency as targets, based on four main domains: actors, legal, regulatory, and institutional setting, policies and planning, and information and knowledge [23]. The main principles of groundwater governance as listed by [22] are: integrated water resource management, comprising both quantitative and quality aspects, the need for co-governance with activities that impact the subsoil, vertical integration, from the national level to the local one, and the coordination with other economic activities. Despite few publications addressing groundwater governance in a specific country or region [24], several studies present groundwater governance state-of-art in worldwide locations, showing the significance of the concept [3,25-28]. Even the broader study made in the framework of the so-called Groundwater Governance-A Global Framework for Action does not allow access to country-scale data) [24].

The concept of groundwater governance as defined above follows the broader governance definition proposed by [29], as the exercise of political authority and institutions in order to manage societal affairs, and differs from the operational character of management actions. Regarding groundwater management, four main families of tools can be considered [24]: technical instruments, managerial actions, and planning and regulatory and economic instruments.

The relevance of groundwater governance is even higher in regions such as the Azores archipelago, where groundwater explains about $98 \%$ of the overall water supply [30-32] and, thus, should be a key issue of the environmental policy (Figure 1). Water supply is run directly by 15 of 19 municipalities, encompassing about $47.3 \%$ of the Azores inhabitants, and in the remaining municipal companies $(2 ; 10.8 \%)$ or semi-autonomous utilities are responsible $(2 ; 41.9 \%)$ [32], thus, the relationship between groundwater science, instrumental toward sustainable development, and the water supply operations is another factor that should accounted for [33].

Following the adaptation of the EU Water Framework Directive (WFD) to the national law, through the so-called Water Law (WL; Law 58/2005), the Azores archipelago was designated as the ninth River Basin District (RBD; so-called RH 9) in Portugal. The subsidiary EU Groundwater Directive was also adapted in the national law (Decree-Law 208/2008), and in 2012 the Azores Government defined the threshold values for the evaluation of the chemical status of groundwater bodies in the Azores River Basin District according to the EU Groundwater Directive (Regional Ordinance 106/2012).

Starting from a state-of-art about groundwater occurrence in the Azores, the objectives of this paper are to (1) discuss the current status of groundwater management in the Azores, which is driven by the WFD and GD EU directives, and (2) make a diagnosis of the groundwater governance status in the archipelago. The lack of comprehensive analysis of groundwater governance advancement in EU member states and at river basin districts, such as the Azores archipelago, is also a tool to enhance the adoption of best practices though a comparison of lessons learned along the process. 


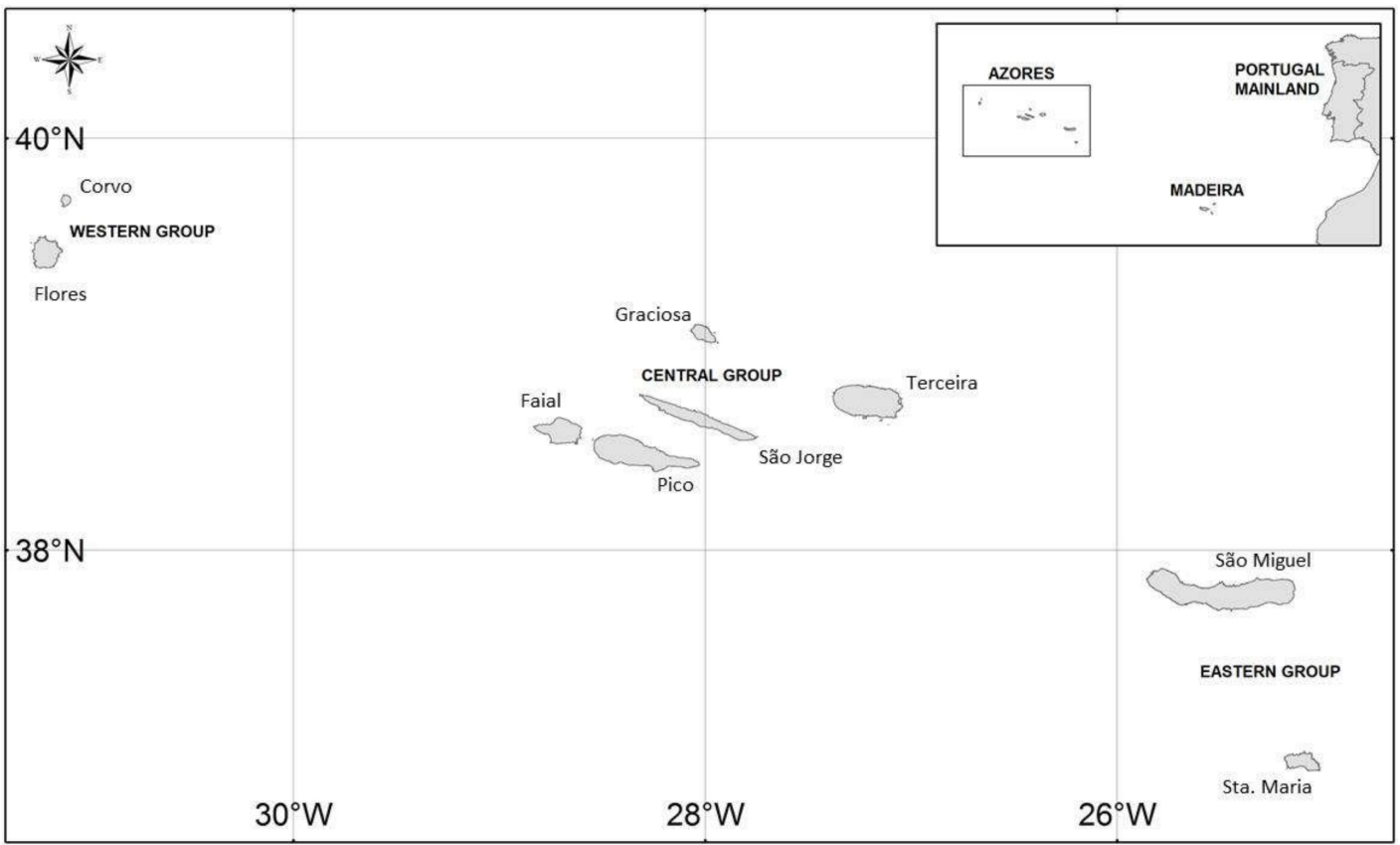

Figure 1. Location of the Azores archipelago in the North Atlantic Ocean.

\section{Geological and Hydrological Setting}

\subsection{The Azores River Basin District}

The Azores archipelago is located in the North Atlantic Ocean, between latitude $36^{\circ} 55^{\prime} \mathrm{N}$ to $39^{\circ} 43^{\prime} \mathrm{N}$ and longitude $25^{\circ} 00^{\prime} \mathrm{W}$ to $31^{\circ} 16^{\prime} \mathrm{W}$. Made by nine volcanic islands, the Azores had a total area of $2322 \mathrm{~km}^{2}$ and about 245,283 inhabitants in 2016 [34]. GDP in the Azores is about 2.1\% of the Portuguese GDP, and the economic activity is dominated by tertiary sector activities, with an increasing tourism pressure. However, livestock is the main primary sector activity and, as a whole, agriculture, livestock production, hunting, forestry and fishing have a GVA of $9.8 \%$, which is four times higher than the country value. Land use is dominated by agriculture, mainly pasture land, with about $56 \%$ of the land area, as well as forest (22\%) and natural vegetation (13\%) [35], and a total of 1.71 livestock units/ha of the utilized agricultural area (129,793 ha) were registered in the archipelago in 2016 [34].

The Azores RBD has a total of $10,045 \mathrm{~km}^{2}$, of which $76.6 \%$ are coastal waters $\left(7693 \mathrm{~km}^{2}\right)$ and $23.4 \%$ is inland area. In the Azores RBD a total of 63 surface water bodies (10 rivers; 23 lakes; three transitional; 27 coastal) and 54 groundwater bodies are delimited [31]. Along the second cycle of the Azores RBD management plan, the status of surface water bodies was classified as $41.3 \%$ in high status, $28.6 \%$ in good status, $19 \%$ in moderate status, and $11.1 \%$ in poor status [31]. The status of the groundwater bodies will be further addressed in the current paper.

\subsection{Geology Outline}

The islands are spread along a complex geodynamic setting, near the triple junction between American, African, and Eurasian lithospheric plates, this context being reflected by intense seismic and volcanic activities [36]. Since the settlement in the late 14th century, a total of 28 eruptions took place in the archipelago area, both inland (15) or offshore (13), the latter of which corresponded to a submarine eruption that took place in 1998-2000 near Terceira island [37,38].

All the islands and the few islets that made the archipelago are of volcanic nature, being the oldest island from the late Miocene, with subaerial lava flows dated from 8.12 Ma [39]. Resulting from the dominant volcanic activity type, that ranges from effusive to highly-explosive eruptions, the several islands present diverse geological features: islands such as Santa Maria, Pico, and São Jorge are 
mainly made from basaltic rocks, associated to the predominance of Hawaiian and Strombolian-type eruptions [36,40-42]; in other islands, such as São Miguel, Terceira, Faial and Graciosa, and Flores and Corvo, more evolved rocks and volcanic form are also observed, as trachytic domes, pumice fall deposits, ignimbrites, and other pyroclastic flow deposits, mainly associated to eruptions more explosive in character [36,43-50]. In the latter islands, some central volcanoes with large summit calderas are also to be observed.

\subsection{Water Resources Setting}

Mean annual precipitation in the Azores equals $1930 \mathrm{~mm} / \mathrm{a}$, therefore, largely exceeding the mean annual actual evapotranspiration (581 mm/a) [51]. Nevertheless, mean annual precipitation is highly variable in the archipelago, in the range from $966 \mathrm{~mm} / \mathrm{a}$ (Graciosa island) to $2647 \mathrm{~mm} / \mathrm{a}$ (Flores island), while mean annual evapotranspiration ranges between $561 \mathrm{~mm} / \mathrm{a}$ to $625 \mathrm{~mm} / \mathrm{a} /$ Flores island).

Surface runoff is usually of a torrential nature, in the range between $1.30 \times 10^{7} \mathrm{~m}^{3} / \mathrm{a}$ (Corvo island) to $2.77 \times 10^{8} \mathrm{~m}^{3} / \mathrm{a}$ (Pico island). Permanent rivers only occur on the islands of Santa Maria, São Miguel, Faial, and Flores. Some of the rivers have water quality problems due to agricultural pollution, as well as insufficient coverage of sewage drainage and treatment systems in some urban areas [52].

A total of 88 lake water bodies are spread in the archipelago, with the exception of Santa Maria, São Jorge, and Faial islands [51]. These lakes present a total water storage of about $1.1 \times 10^{8} \mathrm{~m}^{3}[31,51]$, and are often suffering from eutrophication processes [53,54]. Some lakes also show a geochemical signature of volcanic origin [55].

\section{Groundwater Occurrence and Status in the Azores}

\subsection{Groundwater Bodies Delineation and Resources}

Nowadays, a total of 54 groundwater bodies are delimited in the Azores RBD, according to a scheme adopted since the initial characterization of the river basin made in order to comply with the WFD [56], which also have followed with the methodology proposed by the Directive Common Implementation Strategy (Figure 2) [57]. This delineation corresponded to the identification of aquifer systems made during the preparation of the Regional Water Plan [51], and followed a set of criteria, such as the geology, namely the lithological characteristics, stratigraphy and tectonic features, and the hydrogeological setting, as well as water management factors. Currently, the water administration is developing a set of studies in order to evaluate the need to deliver a new groundwater bodies' delineation to come to force for the next 2021-2027 RBD planning cycle using also the criteria proposed by [57].

These groundwater bodies may encompass two main types of aquifers, namely perched-water bodies, usually in altitude and being discharged by numerous springs spread in the flanks of the volcanic edifices, and basal aquifers [58]. The latter occur mainly in the coastal zone, usually presenting a very low hydraulic gradient due to the highly-permeable volcanic rocks.

The classification of groundwater bodies was achieved according the successive application of several tests for both the chemical and quantitative status (general groundwater quality; saline or other intrusion; surface water; groundwater dependent terrestrial ecosystems; drinking water protected areas; water balance), the either good or poor status being the final disposition equal to the worst result obtained along the process. A total of 51 from 54 groundwater bodies (94.4\%) are in good status, being that the failures comply with the WFD criteria due to coastal aquifer salinization, namely in Graciosa and Pico islands where the poor chemical status groundwater bodies occur (Figure 3). Salinization of coastal aquifers is the main groundwater quality concern in the Azores, presenting a challenge to the water supply $[59,60]$. The prospective analysis made during the 2016-2021 RBD planning cycle shows that, if measures delivery is successful, all groundwater bodies will achieve good status from 2021 ahead [31]. 


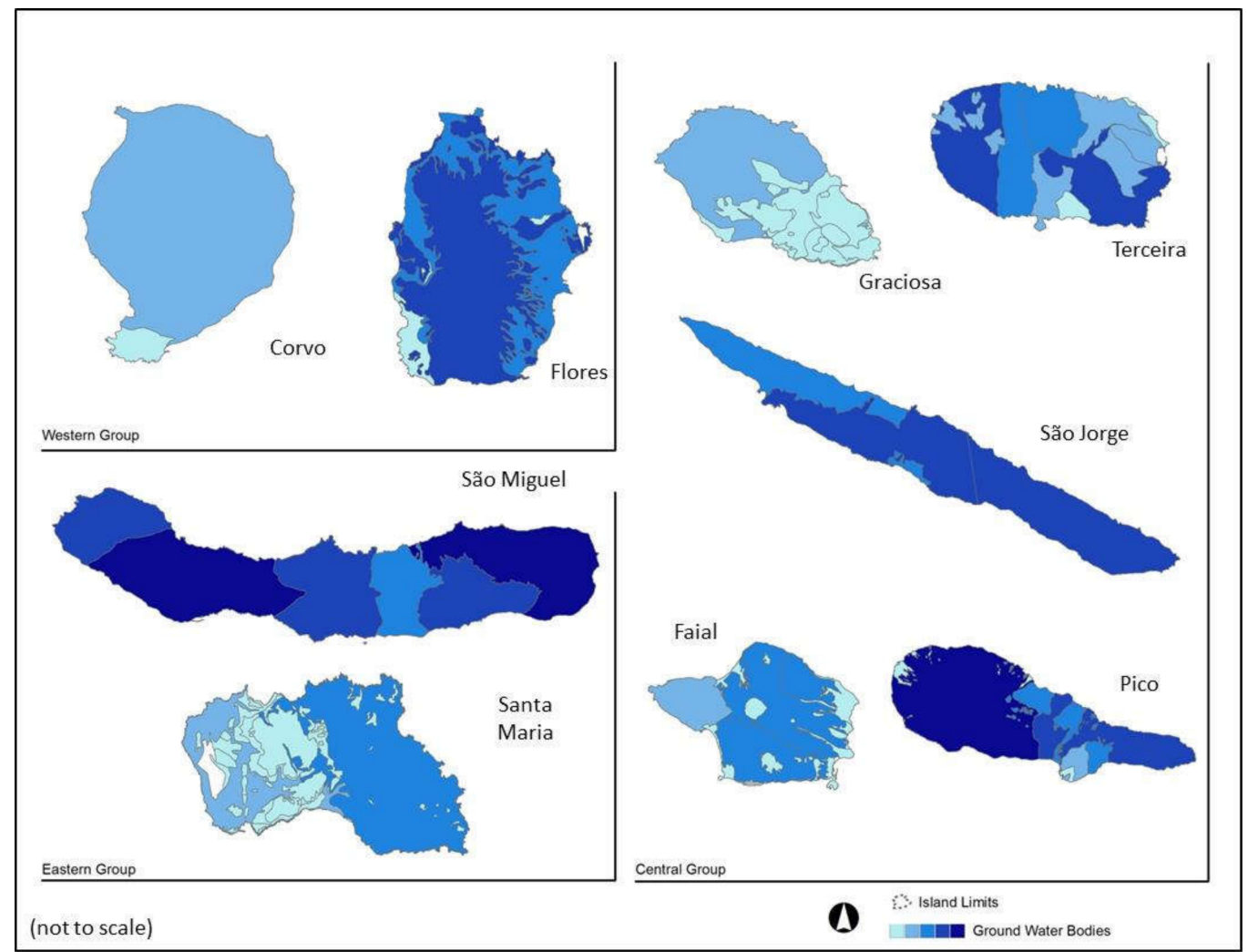

Figure 2. Groundwater bodies' delineation in the Azores RBD.

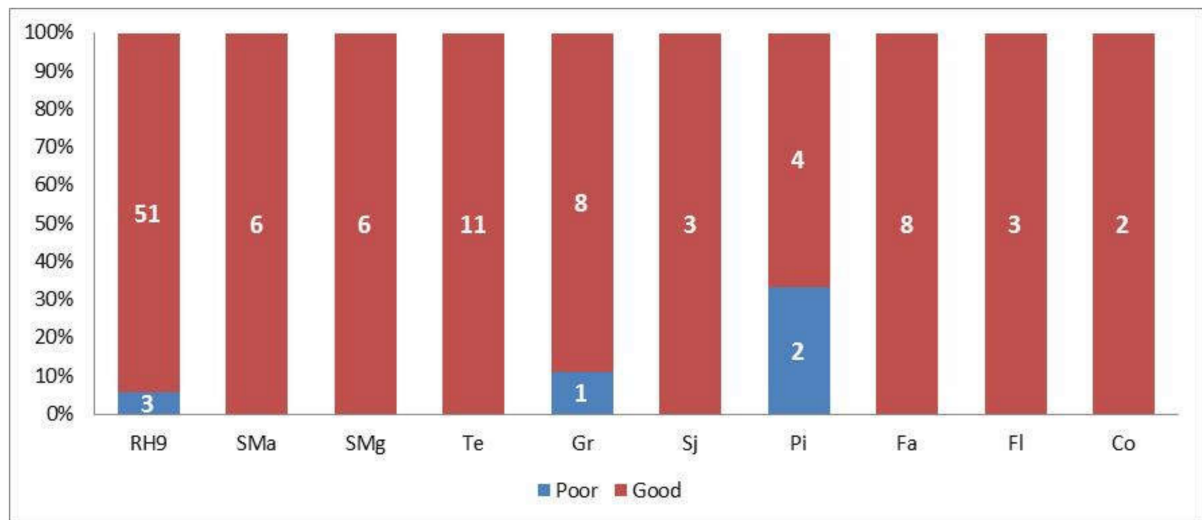

Figure 3. Groundwater bodies status in the Azores RBD in year 2015 (data from [28]; Poor and Good: groundwater bodies, respectively, in poor and good status according to the WFD criteria).

\subsection{Groundwater Abstraction}

Groundwater abstraction for water supply sums up a total of $4.67 \times 10^{7} \mathrm{~m}^{3} / \mathrm{a}$, largely exceeding the surface water abstraction $\left(7.94 \times 10^{5} \mathrm{~m}^{3} / \mathrm{a}\right)$. On seven of the nine islands all water supply is made from groundwater sources, with the exception of Pico and São Miguel, which equals, respectively, $91.1 \%$ and $97.6 \%$ of the total water supply. Groundwater abstraction is higher in the most populated islands, such as São Miguel $\left(2.53 \times 10^{7} \mathrm{~m}^{3} / \mathrm{a}\right)$ and Terceira $\left(1.06 \times 10^{7} \mathrm{~m}^{3} / \mathrm{a}\right)$, and a close relationship is observed between groundwater abstraction and the number of inhabitants of each island $(r=0.998)$ (Figure 4). Groundwater dependence can be useful in order to raise awareness of groundwater management, but at least in the long-term can become a vulnerability regarding the degradation of the resource-base [17]. 


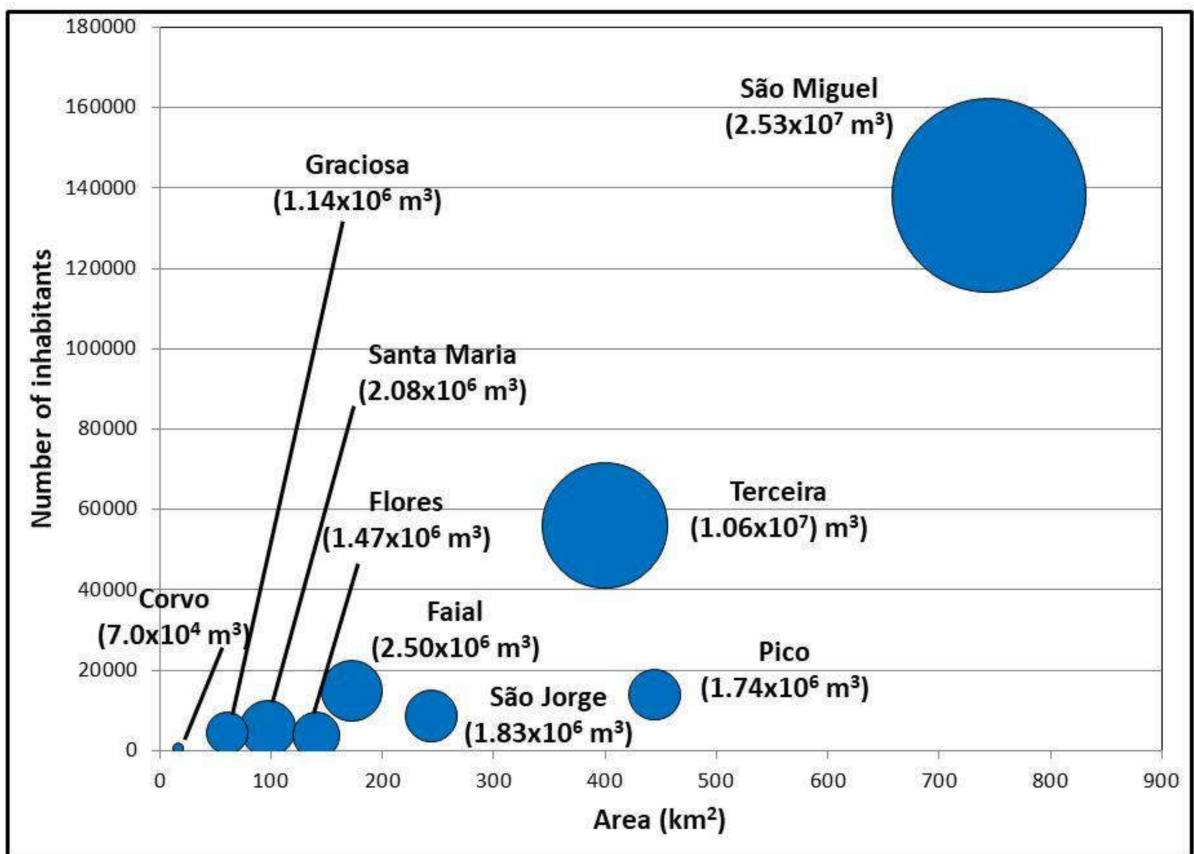

Figure 4. Groundwater abstraction in the several islands from the Azores archipelago (circle diameter proportional to groundwater abstraction).

Groundwater abstraction lies mainly in springs discharging from perched-water bodies spread all over the archipelago, corresponding to a total of 1162 springs being appropriated, $75.6 \%$ of which are located on São Miguel island (Figure 5). Water supply also relies on drilled wells on seven of the nine islands, with the exception of Flores and Corvo (Figure 6). Spring discharge is usually higher in lava flows compared to springs from pyroclastic rocks [61], being the highest mean annual discharge measured in a spring from Terceira Island $\left(6.76 \times 10^{-2} \mathrm{~m}^{3} / \mathrm{s}\right)$ [31]. Nevertheless, spring discharge is usually much lower in the summer period, suggesting a low regulation capacity of the perched-water bodies as shown by the two-month time lag between precipitation episodes and discharge peaks observed on some islands [58].

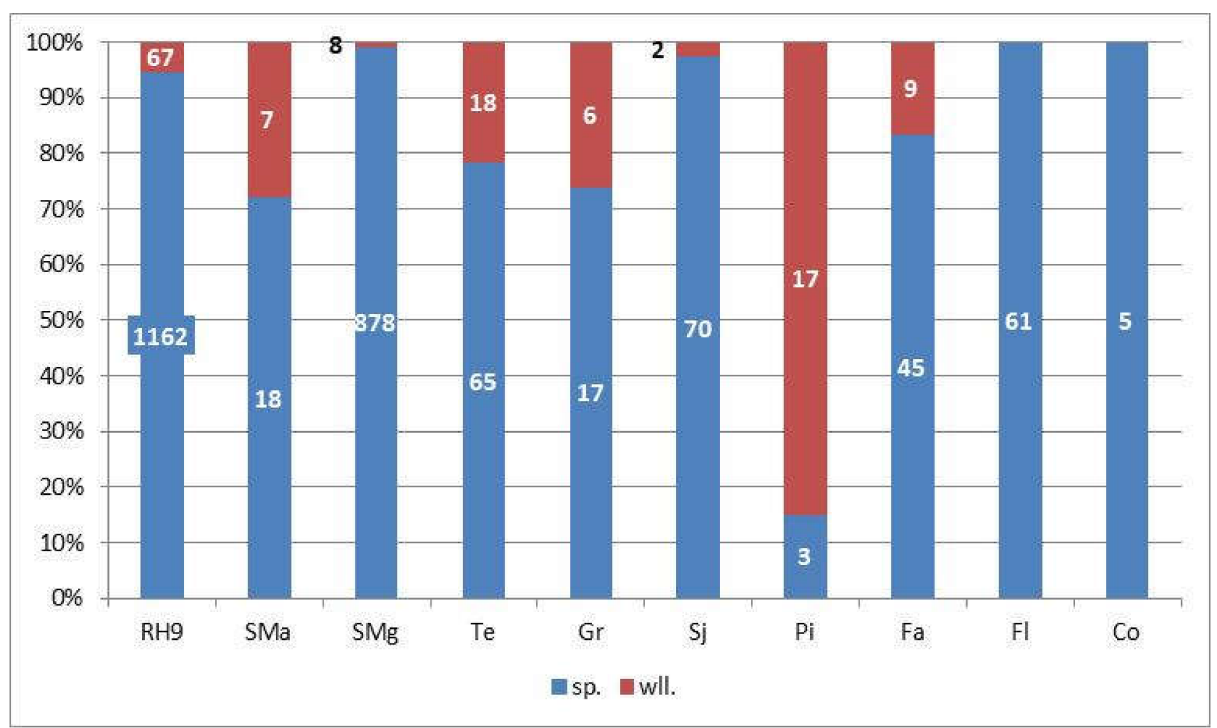

Figure 5. Number of springs and wells used for water supply in the Azores archipelago (sp.: springs; wll.: drilled wells). 


\subsection{Groundwater Quality and Pollution Risk}

In addition to salinization (mentioned in Section 3.1), other quality problems are observed, despite not being widespread, as nutrient and microorganism fecal pollution, mainly due to agriculture and waste water discharges [62-64], or local fluoride enrichments in São Miguel [65] and Terceira [66]. The latter is suggested to be closely associated to a volcanic activity source, which significantly alters the groundwater composition as shown by the numerous mineral waters spread along the archipelago [67,68]. Pollution risk mapping made from the overlap of the DRASTIC index, land use, and net N-pollution load have shown that groundwater pollution risk is very low to moderate [69]. The DRASTIC index is based on scores attributed to seven factors (depth to the water table; net recharge; soil media; aquifer media; topography; impact of vadose zone; hydraulic conductivity) being a useful methodology to characterize groundwater vulnerability to pollution [70].

\subsection{Groundwater Monitoring}

In the Azores RBD only the groundwater chemical status is monitored, a project started in 2003 [62,71,72]. A total of 69 springs and 32 drilled wells are monitored on nine islands (Figure 6A). The percentage of groundwater bodies being monitored nowadays is $64.8 \%$ of the total, and considering each island this value ranges between 33.3\% (Graciosa island) and 100\% (São Miguel, São Jorge, and Flores) (Figure 6B). Considering only the 35 groundwater bodies being monitored, only $5.7 \%$ have representative networks, considering a threshold value of $80 \%$ for the representative index computed as proposed by [73] (Figure 6C; Table 1).

Table 1. Representative index for the chemical status monitoring networks in the Azores RBD.

\begin{tabular}{ccc}
\hline Island & Gwb Monitored (\%) & Representativity Index (\%) \\
\hline Santa Maria & 66.7 & $33.4-67.8$ \\
São Miguel & 100 & $60.5-83.7$ \\
Terceira & 72.7 & $51.3-79.4$ \\
Graciosa & 33.3 & $57.8-91.5$ \\
São Jorge & 100 & $40.8-57.5$ \\
Pico & 66.7 & $31.0-70.3$ \\
Faial & 37.5 & $47.3-73.8$ \\
Flores & 100 & $15.5-55.5$ \\
Corvo & 50.0 & 50.4 \\
\hline
\end{tabular}

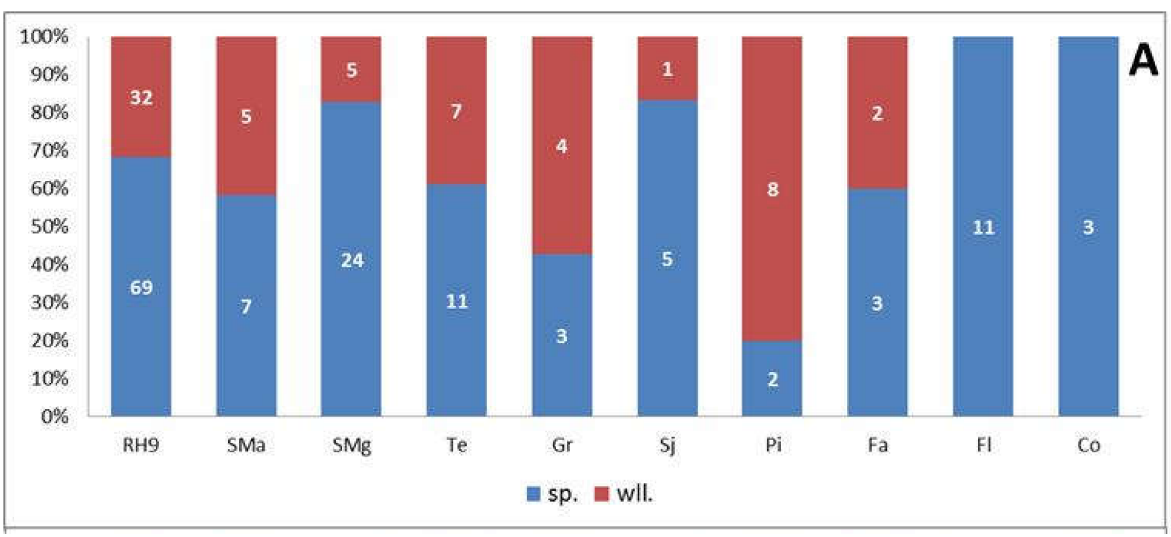

Figure 6. Cont. 


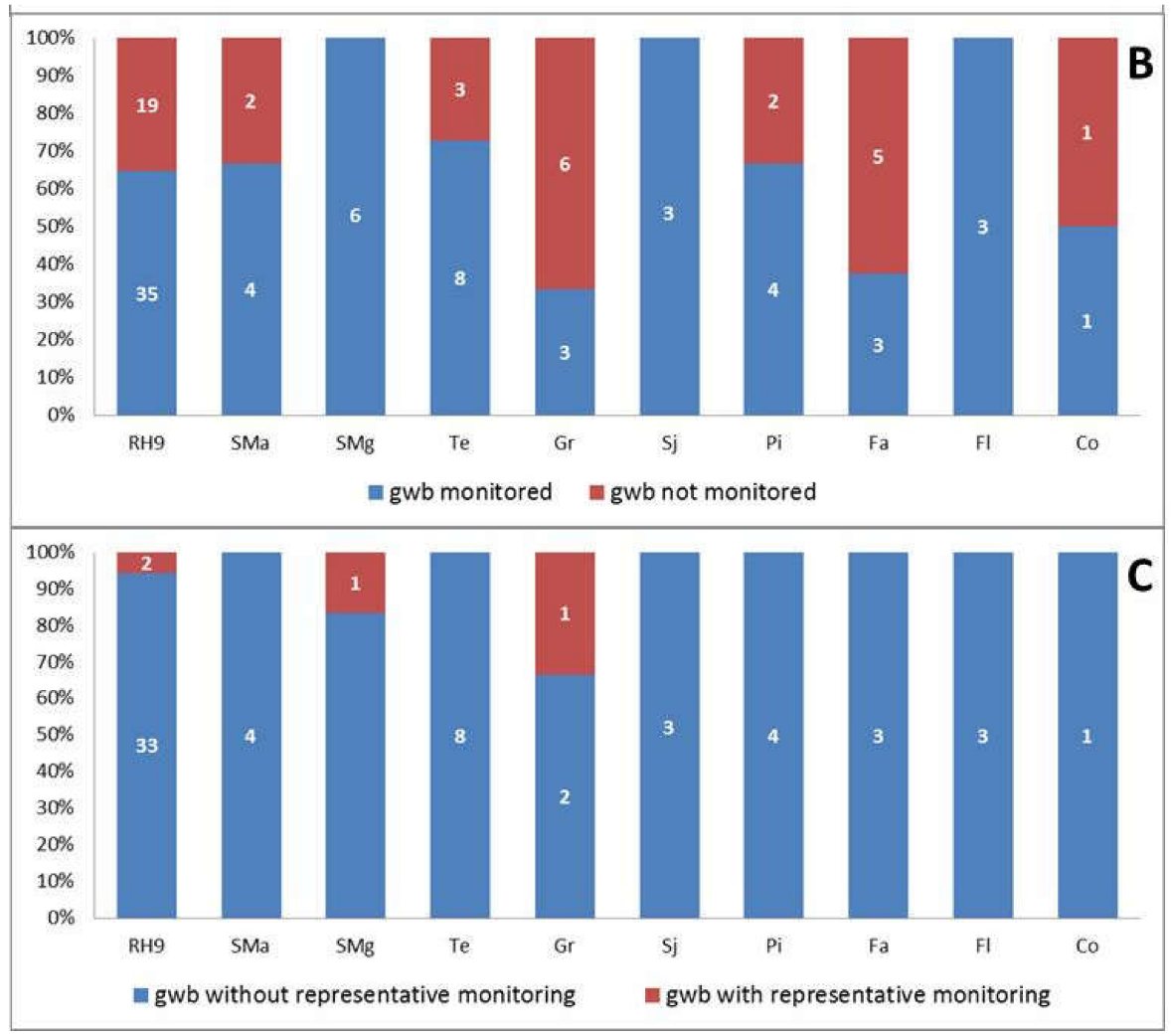

Figure 6. (A) The number of springs and drilled wells being monitored; (B) the number of groundwater bodies with chemical monitoring; and $(\mathbf{C})$ the number of groundwater bodies with representative monitoring network for chemical status.

\section{Groundwater Planning and Management}

\subsection{Legislation and Regulatory Framework}

Groundwater is traditionally privately appropriated in Portugal, depending on the land ownership rights and on licensing and taxation by the public administration nowadays. According to the Portuguese Law 54/2005, which came to force on 15 November 2005, the so-called public water domain (PWD) comprises coastal waters, rivers, lakes, and lagoons, both navigable and not-navigable channels, as well as groundwater on public land. Under a permit/title of use, emitted by the competent water authority, water use by private entities in the PWD is allowed, which may imply a fee payment. For example, artificial recharge or injection operations have to be preceded by a permit process.

Under the same law, the exploration of groundwater on private land, which is considered to be a private resource, has to be subject of a title of use whatever the objective of the water user (human supply, irrigation, industrial and recreational uses). Nevertheless, all wells equipped with a pump up to $5 \mathrm{hp}$ only need to be communicated by the owner to the water authority, independently of their depth and if no major impacts are expected to occur. If the pump has more than $5 \mathrm{hp}$ a title of use is required, following registration and authorization issued by the water authority, which may imply the payment of a license if the well is located in designated sensitive areas, which also requires a permit application.

The administration of the Azores RBD is pursued by the Regional Directorate for the Environment, from the Energy, Environment, and Tourism Secretariat of the Azores government, which is responsible for the overall management and protection of groundwater resources in the archipelago, including water resources planning and the pursuing of all legal and regulatory frameworks. The Azores water authority acts in a vertically-integrated system, being responsible for all nine islands of the 
archipelago, with representatives on all islands. A synthesis of the evolution of the institutional framework responsible for water management in the Azores is reported in the literature [32].

The legal framework plays an important role in the architecture of groundwater governance, for example, in what concerns the clear definition of responsibilities of all stakeholders [74]. The main legal and regulatory framework for groundwater management in the Azores is listed in Table S1, being strongly based on national and European Union-derived legislative initiatives.

\subsection{Planning in the Context of the Water Framework Directive}

The first integrated water resources plan adopted in the Azores corresponds to the Regional Water Plan (ARWP) which only came to force in 2003 despite an early elaboration and public consultation [51]. In this plan, groundwater resources received, for the first time, full consideration in the Azores RBD as, previously, the main efforts in the public water policies were the fulfilment of EU directives requirements, such as the ones for wastewater, and the control and remediation of eutrophication in lakes [53,54].

As a result of the ARWP widespread approach, a number of measures were proposed to be developed between 2003 and 2013, organized along 20 programs, and, secondly, in 38 projects, grouped according nine thematic areas, and corresponding to a budget of 228 million Euros [51,75]. Groundwater issues were directly and indirectly reflected in several projects, the most important of which were the further characterization of groundwater bodies' status, monitoring, water supply sources protection, groundwater abstraction licensing, diffuse pollution control, and sealing of uncontrolled municipal waste disposal sites.

Nevertheless, as showed through an external evaluation the delivery of the ARWP was unsatisfactory regarding several goals [75]. In the case of groundwater resources, the most successful project was the protection of groundwater supply sources, through a hydrogeological study made between 2001 and 2003 in São Miguel, followed by another made between 2006 and 2008 in the remaining islands, complemented by a study of the economic impact of the associated land use restrictions [76,77]. About $10.9 \%$ of the archipelago area belongs to a water supply protection area, respectively $0.18 \%$ to the immediate protection area, $1.73 \%$ to the intermediate area, and the remaining to the enlarged protection area $(8.97 \%)$. Only in the immediate protection areas, are all human activity forbidden, with the exception of the ones needed for water supply maintenance. Nowadays, measures to control the diffuse pollution from pasture lands are still to be defined in the water supply protection area, which limits the effectiveness of the latter to protect groundwater quality. Nevertheless, a high portion of the water supply sources' protection areas belong to environmental conservancy areas, which reduces the impact over economic activities.

In compliance with the WFD and WL requirements two RBD management plans were already developed, the first of which was adopted in March 2013, therefore, with a considerable delay regarding the original planning cycle (2009-2015), while the second, corresponding to the second planning cycle (2016-2021), was completed in due time (December 2015) [31,32,78]. The number and the geometry of the groundwater bodies were kept unchanged from one planning cycle to the other, but, currently, studies are ongoing in order to evaluate the actual delineation of groundwater bodies and proceed to a new one whenever necessary.

The program of measures proposed along the Azores RBD second planning cycle (2016-2021) comprises a total of 47 measures, namely 18 basic measures and 29 supplementary, corresponding to a total overall budget of 78 million euros ( $51 \%$ to basic measures and $49 \%$ to supplementary measures) [31,32]. From the 47 measures to be implemented, 25.5\% are directed to a specific water body, while the remaining has a more holistic implementation throughout the RBD. From the former group, about $42 \%$ are associated with groundwater bodies (one basic measure and four supplementary measures).

From the set of basic measures being proposed, three are directly associated with groundwater issues, such as the need to improve monitoring activities all over the islands, through the development of quantitative and chemical surveillance networks, or the mitigation of seawater intrusion in groundwater bodies considered to be in poor status due to salinization in Graciosa and Pico islands. 
Nevertheless, other basic measures also have a positive impact over groundwater management and protection, namely though the reduction of diffuse pollution loads, the control of groundwater abstraction, capacity building of human resources, and the development of decision support information systems.

Among the supplementary measures set, several are directly associated with groundwater issues, namely the definition of the regulatory framework to be applied to the groundwater recharge areas in order to prevent or constrain human activities, therefore preventing pollution and enhancing water quality protection, the need to develop studies to reevaluate groundwater bodies' boundaries and geometry, as well as the interactions with groundwater-dependent ecosystems, and the increase of scientific knowledge in order to sustain science-based policies. The characterization of particular polluted sites is also pointed out, in order to assure groundwater monitoring and remediation, if necessary, namely in airport and military base facilities. Other supplementary measures are also listed that, despite an indirect connection to groundwater, are also of importance, such as the empowerment of the general public and the access to information by all stakeholders.

\subsection{Perception of Stakeholders}

A brief survey on water management in the Azores was accomplished, in which 43 specialists working for four stakeholder institutions were consulted and had the opportunity to share their opinion. For that purpose a questionnaire was prepared and delivered to all participants in May 2017, comprising 12 questions of interest to groundwater protection and management that were later collected by the institutions (Table 2). Previously, all respondents were kept informed about the objectives of the survey. For each question the participants on the survey have to choose one of five possible answers to each question, which were organized in order to show increasing agreement/effectiveness/integration, and after which the results were grouped for each question based on the selections of each individual. The stakeholders were selected as a function of their role in what concerns water management, thus, a water supply municipal provider, a consulting company being responsible for the RBMP, the local university, and the government body that acts as the water authority in the Azores.

Results showed contrasting views, resulting from insufficient delivery by bodies responsible for water management (Figure 7). If water policies are considered to be clearly established (Q1), the lack of agreement $(\mathrm{Q} 2)$ and cooperation between public and non-public water managers $(\mathrm{Q} 3)$ is still a problem, which may affect the valuing and protection of groundwater resources in the Azores. The lack of leadership by the water authority is also reflected by the fact that about $47 \%$ of the respondents facing Q9 considered that legislation as not fully pursued, and only $23 \%$ stated that water policies are enforced in a satisfactory manner (Q7), which can be associated with a perception of an inefficient oversight in the nine islands. Nevertheless, the perception about the capacity of the water administration to provide permits/titles of use in a timely manner seems to be positive (Q6).

The cooperation between the water administration and water users is considered to be not successful, as $49 \%$ and $51 \%$ of the respondents are more or less satisfied when facing Q10 and Q11, respectively.

The majority of the responses shows that the perception about the water monitoring program, in due course, is positive (Q8). Nevertheless, as the quantitative monitoring of groundwater bodies is still to be achieved in the Azores, responses suggest that, despite the instrumental role of groundwater for the water supply, there is a need to increase awareness about groundwater protection even among responsible bodies. This issue shows that groundwater is still often an invisible resource [79], and the lack of awareness causes a narrow interface is to be drawn between the status and dynamics of the groundwater-resource base and risks when facing vested interests [80]. This also explains the negative to neutral perception about the science contribution toward water management (Q12). Nevertheless, despite the need for more science-driven groundwater management processes, lengthy responses should be avoided through counterbalancing faster and technological solutions [17]. 
Table 2. Questions related to groundwater management in the Azores in the stakeholder survey.

\begin{tabular}{cl}
\hline Ref. & \multicolumn{1}{c}{ Subject } \\
\hline Q1 & Water policies are clearly established. \\
Q2 & The water policies have the agreement from all public and non-public bodies with responsibilities in water management. \\
Q3 & Is the cooperation between public and non-public bodies with responsibilities in water management effective? \\
Q4 & Are water policies integrated with land use policies? \\
Q5 & Are water policies integrated with waste management policies? \\
Q6 & The water administration has responsiveness capacity in terms of emission of title of use/permit issuing. \\
Q7 & Are the water policies' enforcment adequate? \\
Q8 & Is groundwater monitoring adequate? \\
Q9 & Is national and EU legal and regulation framework fully pursued? \\
Q10 & Is the cooperation between water administration and water users adequate? \\
Q11 & Are citizens and NGOs adequately consulted before the implementation of a new water management policy/procedure? \\
Q12 & The cooperation between water administration and scientific bodies effective? \\
\hline
\end{tabular}

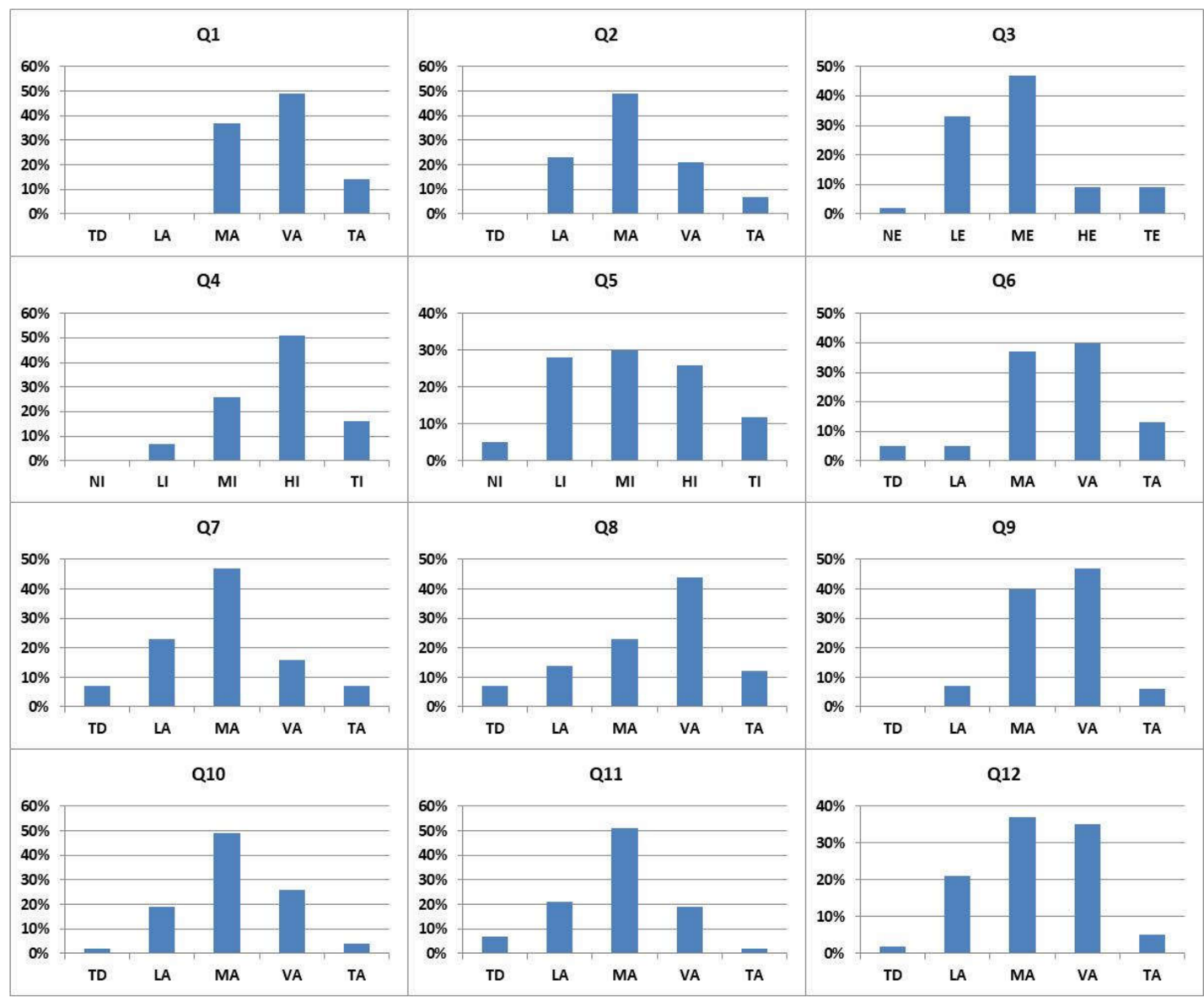

Figure 7. Histograms for the several responses to questions made about groundwater management in the Azores (TD: totally disagree; LA: little in agreement; MA: more or less in agreement; VA: very agree; TA: totally agree; NE: non-effective; LE: low effectiveness; ME: more or less effective; HE: highly effective; TE: totally effective; NI: totally non-integrated; LI: limitedly integrated; MI: more or less integrated; HI: highly integrated; TI: totally integrated).

\section{Discussion}

To maximize the benefits that can be obtained from groundwater use both groundwater management and governance improvement is needed [23]. In order to make a diagnosis of the governance state-of-art in the Azores the benchmark criteria proposed by $[1,80]$ were applied, also allowing further discussion of the results, taking in account the management pitfalls already presented in previous sections (Table 3). Those criteria evaluate the effectiveness of provisions that came to force 
and the capacity for a proper groundwater governance, namely in areas where groundwater is already pressured $[1,80]$. Results are further discussed considering the four main components of groundwater governance [23]: (1) information and knowledge; (2) legal and regulatory framework; (3) policies, planning and finance issues; and (4) actors in the groundwater governance scheme.

\subsection{Information and Knowledge}

Groundwater-related data is a key factor to groundwater governance and management, leading to appropriate solutions, which have a sound diagnosis and knowledge on the resource-base [24,81].

Some constraints regarding water management in the Azores archipelago were already grouped into three main issues [32]: insufficient funding, lack of empowerment by the water authority, and no consideration of the economic dimension. An example of the impact of those constraints is the lack of quantitative monitoring of groundwater bodies, which also, despite the amount of the resource-base, enables the establishment of a sounded-based right allocation framework [82]. Thus, the due authorization to groundwater abstraction is granted with a certain degree of uncertainty.

Monitoring and groundwater governance are interdependent; as if the latter depends on the knowledge about the resource base offered by the former governance, itself, establishes a framework to monitoring as shown by the EU WFD and GD requirements [24]. Therefore, besides the fulfillment of WFD requirements in due time in the Azores, such as the timely adaptation of the 2016-2021 RBMP, funding can limit the implementation of the set of measures proposed regarding groundwater, diminishing governance gains.

In addition to the inexistence of a quantitative monitoring network, the absence of quantitative data also limits the development of numerical management models to aquifers, thus diminishing governance technical capacities. The lack of knowledge may also imply that the government agency in charge is not able to advance from a limited resource development approach to a resource and protection stage [83]. Nevertheless, in the Azores, and despite the limited data on quantitative issues, this evolution has already occurred, mainly due to the compliance regarding the EU WFD and GD.

Another consequence of limited knowledge about the resource base and a low degree of information dissemination is a diminished capacity to resolve emerging conflicts [84] which, in the Azores, may occur between government agencies that represent diverse sectorial interests.

Table 3. Check-list of benchmarking criteria to evaluate groundwater governance in the Azores (0: non-existent; 1 : incipient; 2: acceptable; 3 : optimum) (criteria according to $[1,80])$.

\begin{tabular}{ccll}
\hline Type of Provision/Capacity & Ref. & \multicolumn{1}{c}{ Criterion } \\
\hline Technical & 1 & Existence of basic hydrogeological maps \\
& 2 & Groundwater body/aquifer delineation & 3 \\
& 3 & Groundwater-piezometric monitoring network \\
& 4 & Groundwater-pollution hazard assessment & 0 \\
& 5 & Availability of aquifer numerical management models \\
& 6 & Groundwater-quality monitoring network & 0 \\
& 7 & Waterwell drilling permits and groundwater use rights \\
& 8 & Instrument to reduce groundwater abstraction & 2 \\
& 9 & Instrument to prevent waterwell construction & 2 \\
& 10 & Sanction for illegal waterwell construction & 2 \\
& 11 & Groundwater abstraction and use charging & 1 \\
& 12 & Land-use control on potentially-polluting activities \\
& 13 & Levies on generation/discharge of potential pollutants \\
& 14 & Government agency as ground-water-resource guardian & 2 \\
& 15 & Community aquifer management organizations & 0 \\
\hline Cross-sector policy coordination & 16 & Coordination with agriculture development & 1 \\
& 17 & Groundwater-based urban/industrial planning
\end{tabular}




\subsection{Legal and Regulatory Framework}

Despite the modernity in what concerns the water legislation framework in force in the Azores, shown by the integrative approach and the introduction of tools for planning and monitoring [74], some of which were already provided for in legislation prior to the adoption of the WFD, the majority of the laws and regulations are of national and EU origin. Thus, the needed adaptation of the groundwater legal framework to the financial, technological, and institutional capabilities, as well as to the geographical and environmental specificities, customs, culture, political system, and usual practice [85], is largely lacking in the Azores, in which the local government has, by the Portuguese Constitution and the autonomous government power, specific legitimacy to manage water resources at the regional level [32,75]. From Table S1 it is possible to show the restricted number of dispositions that are the responsibility of the local government, and regarding the adaptation of EU directives only the establishment of threshold values was accomplished. This lack of adaptation may also explain the lack of enforcement of the laws and regulations in force nowadays.

The ability to provide permits/sanctions as well as to reduce groundwater abstraction exists, but as affected by the lack of quantitative data delivery through monitoring is classified as acceptable. The same score is attributed to the government agency being responsible for the groundwater management due to their lack of funding and human resources, resulting in a lower delivering of their goals.

\subsection{Policies, Planning, and Financial Issues}

Only a limited number of countries have adopted specific policies regarding groundwater, and the ones that came to force present a broad range in what concerns focus, scope, type, and degree of detail [24]. A close relationship can be established between the advance of groundwater governance and the economic development, and in countries which reached an advanced management stage in groundwater policies have evolved from a limited resource control and protection scope toward a more integrated approach to exploitation, control, and protection of water resources and a more advanced linkage to other policy domains. Nevertheless, even in countries that have achieved an advanced management model, inconsistent linkages with other sectorial policies are observed, resulting in an excessively-limited policy scope [24].

In the Azores archipelago this limited policy scope is observed. Cross-sectorial approaches also have to be strengthened, namely with agriculture development policies. Despite the increased awareness regarding the environmental impact of activities developed at agricultural holdings, which may limit access to external funding of the mandatory adoption of good practices, including the reduction of fertilizer use, in vulnerable areas, land use control in groundwater source protection areas is still to be achieved, requiring some sort of compensation payment to farmers/land owners. This subject is of capital importance as, in the majority of the islands, with the exception of Faial and Corvo, recharge areas are at least partly occupied both by natural vegetation and forests and by pasture land [31].

The failure to account for the economic dimension of the groundwater governance explains the low scores in what regards taxation of groundwater abstraction/discharge of pollutants, as an economic mechanism is not yet established. The adaptation of any measures in order to compensate compliance or any groundwater protection action, which can be a kind of counterbalancing approach to enhance groundwater governance [1], is also not considered.

\subsection{Actors in the Groundwater Governance Scheme}

Those intervening in the groundwater governance framework are heterogeneous in nature and pursue such diverse interests and objectives that can be conflictual and an obstacle for effective cooperation. Therefore, a key factor of success is to call for a sense of urgency regarding groundwater governance and management, as the lack of awareness may result in low funding and in low 
prioritization [24]. In the Azores this lack of understanding is undermining the capacity of the government agency in charge, which, despite having a clear mandate and competencies for groundwater management, disperse their efforts and attributes a clearer priority to the remediation of surface water bodies' eutrophication. Thus, even in a water resources integrated management scheme, groundwater is not the focus, even in a region where about $98 \%$ of the water supply is satisfied by groundwater sources, which may be explained by the fact that resources exceed largely the demand. The low prioritization conceded to groundwater control and protection also explains that the applications of funds from EU sources are limited and regarding groundwater the Azores Government only applies EU funds to chemical monitoring of groundwater bodies and sporadically to specific projects, such as the study to evaluate the actual delineation of groundwater bodies.

Results suggest that public participation is, in general, unsuccessful, and taking to account the five key indicators of the success of public participation provided by [86], namely the scope of the participation, the effectiveness of communication, the capacity building, the timing, and the financing of the process, public consultation processes in the Azores fails to achieve success in two of five of these criteria: insufficient capacity building, due to lack of knowledge by the public, and a lack of effectiveness regarding communication. Therefore, more efficient information dissemination and contribution collection, besides e-forms, workshops, or stakeholder interviews, which were usually adopted during water planning in the Azores, should be envisaged. Nevertheless, increasing accountability and transparency by the water authority, thus contributing to a more robust governance [1], should be pursued in the Azores.

The advantage of the scale factor toward more efficient public participation, common in other small islands where the identification of stakeholders is facilitated, has to be exploited, as well as the easier identification of societal values and local knowledge in small communities that suffer from a certain degree of isolation through centuries [64].

\subsection{A Tentative Benchmark with Other Regions}

A global analysis of groundwater governance has shown that it depends on the achieved degree of groundwater management, on the economic conditions, as well as on the specific needs and conditions, such as in North American and European countries where more attention is given to issues like aquifer protection and groundwater pollution [23]. In the Azores, this main focus is enhanced by the fact that groundwater resources exceed, by far, the water demand, which also contributes to the awareness that the groundwater value is lacking and the quantitative aspects are somehow neglected by authorities and other stakeholders. Land use is the only major focus of groundwater governance in European countries, which is not fully effective in the Azores, as a result of the lack of coordination with the agricultural sector. Since 1976, when the management of water resources was formally recognized as one of the specific powers granted by the national government of the autonomous Azores government, the nexus between water and agriculture has been mainly considered in order to avoid, or diminish, lake eutrophication.

The key management issues which are driving groundwater governance in the Azores nowadays are groundwater pollution, mainly regarding agriculture impacts, coastal aquifer salinization, the lack of sanitation and wastewater treatment, and the satisfaction of an increasing water supply demand, to which tourism is an increasing driver. These major issues are also some of the key management drivers in the UNECE countries, where the development stage of groundwater management is considered to be advanced [23].

As the fulfillment of WFD and GD requirements is also driving groundwater management in the Azores, and considering that the WFD is a landmark that concerns providing a framework for an effective governance scheme [23], if compliance is successful governance will indirectly progress in the Archipelago.

A comprehensive analysis of groundwater governance at the national level is absent, therefore inhibiting a comparison with the Azores regional case study. Nevertheless, and considering the 
delivery of the 2009-2015 River Basin Management Plans in Portugal, which measures the degree of the WFD implementation, it was shown that major constraints are the lack of leadership and insufficient funding [87] and, thus, issues also identified in the Azores in the current study. The lack of political commitment, associated with the lack of awareness, and limited funding are also problems that affect groundwater management and governance in UNECE countries.

\section{Conclusions}

Groundwater is a common-pool resource with both subtractability and low excludability [83]. In the Azores archipelago groundwater resources are of strategic significance, where groundwater abstraction $\left(4.67 \times 10^{7} \mathrm{~m}^{3} / \mathrm{a}\right)$ largely exceeds surface water abstraction $\left(7.94 \times 10^{5} \mathrm{~m}^{3} / \mathrm{a}\right)$, and seven of the nine islands are exclusively dependent on groundwater abstraction to warrant water supply. This dependence on the groundwater-resource base pushes the need for sustainable groundwater management, to which governance is instrumental, but nevertheless is not sufficient to raise awareness of groundwater management as shown by the results from the survey made among specialists from several stakeholder institutions.

The public body responsible for the groundwater management follows a vertically-integrated system, but to fulfil their role needs empowerment. The legal and regulatory aspects also need to be fully adapted to the specific natural, financial, technological, and institutional capabilities, as well as to the social and cultural practices in the Azores, in order to facilitate compliance and enforcing.

The application of the benchmark criteria proposed by [1] to the groundwater governance in order to evaluate the state-of-art in the Azores showed several weaknesses. The governance technical capacities are diminished by the lack of quantitative data, namely by the absence of any quantitative monitoring, which also affects legal and institutional capabilities as, for example, enables the establishment of a groundwater exploration rights allocation framework.

Legal and institutional capacities are also weakened by the failure to account for the economic dimension of the groundwater governance, and a specific system for taxation of groundwater abstraction/discharge of pollutants has still to be proposed, as an economic mechanism is not yet established. The adaptation of any measures in order to compensate compliance or any groundwater protection action, that can be a kind of counterbalancing approach to enhance groundwater governance [1], is also not considered.

Cross-sectorial capacities have also to be strengthened, namely within the agricultural sector, for example, in with respect to land use practices in recharge areas, in general, and in water source protection areas, in particular.

Operational capacities are negatively impacted by the low effectiveness of public participation and the absence of any compensation for the ones pursuing some sort of groundwater protection. Nevertheless, despite the insufficient cooperation and interaction between the water authority and other public and non-public bodies, as well as water users, a management plan was adopted in due time in the scope of the EU WFD. This plan, if fully implemented, will resolve the majority of the issues that are weakening groundwater governance in the Azores, but this accomplishment is threatened by the lack of awareness about groundwater significance, which, in turn, limits, for example, the amount of financial resources needed to develop all the measures proposed in the plan.

The present paper also points to the need of more studies regarding the state-of art of groundwater governance at the EU national and river basin district levels in order to allow the establishment of comparisons and address both similarities and differences in the responses to the challenges of implementing EU groundwater policy.

Supplementary Materials: The following are available online at http:/ /www.mdpi.com/2073-4441/10/4/408/s1, Table S1. Main legal framework for groundwater governance in the Azores archipelago (EU: EU legislation; NL: national legislation; RL:regional legislation).

Acknowledgments: Authors are also grateful for the very valuable suggestions provided by three anonymous reviewers and the editor that helped to improve the original manuscript. 
Author Contributions: J. Virgílio Cruz conceived the research, carried out the data analysis, and wrote the draft of the manuscript. N. Soares implemented the stakeholder survey and processed their results.

Conflicts of Interest: The authors declare no conflict of interest.

\section{References}

1. Foster, S.; Garduño, H. Groundwater-resource governance: Are governments and stakeholders responding to the challenge? Hydrogeol. J. 2013, 21, 317-320. [CrossRef]

2. Foster, S.; Chilton, J.; Nijsten, G.-J.; Richts, A. Groundwater-A global focus on the "local resource". Curr. Opin. Environ. Sustain. 2013, 5, 685-695. [CrossRef]

3. Megdal, S.B.; Gerlak, A.K.; Varady, R.G.; Huang, L.-Y. Groundwater governance in the United States: Common priorities and challenges. Groundwater 2015, 53, 677-684. [CrossRef] [PubMed]

4. Foster, S.; Chilton, P.J. Groundwater: The processes and global significance of aquifer degradation. Philos. Trans. R. Soc. Lond. B 2003, 358, 1957-1972. [CrossRef] [PubMed]

5. Kath, J.; Dyer, F.J. Why groundwater matters: An introduction for policy-makers and managers. Policy Stud. 2017, 38, 447-461. [CrossRef]

6. Konikow, L.; Kendy, E. Groundwater depletion: A global problem. Hydrogeol. J. 2005, 13, 317-320. [CrossRef]

7. Custodio, E.; Cabrera, M.C.; Poncela, R.; Puga, L.-O.; Skupien, E.; Villar, A. Groundwater intensive exploitation and mining in Gran Canaria and Tenerife, Canary Islands, Spain: Hydrogeological, environmental, economic and social aspects. Sci. Total Environ. 2016, 557-558, 425-437. [CrossRef] [PubMed]

8. Custodio, E.; Andreu-Rodes, J.M.; Aragón, R.; Estrela, T.; Ferrer, J.; García-Aróstegui, J.L.; Manzano, M.; Rodríguez-Hernández, L.; Sahuquillo, A.; Villar, A. Groundwater intensive use and mining in south-eastern peninsular Spain: Hydrogeological, economic and social aspects. Sci. Total Environ. 2016, 559, 302-316. [CrossRef] [PubMed]

9. Chang, F.-J.; Huang, C.-W.; Cheng, S.-T.; Chang, L.-C. Conservation of groundwater from over-exploitation-Scientific analyses for groundwater resources management. Sci. Total Environ. 2017, 598, 828-838. [CrossRef] [PubMed]

10. Villholth, K.G. Groundwater assessment and management: Implications and opportunities of globalization. Hydrogeol. J. 2006, 14, 330-339. [CrossRef]

11. Sophocleous, M. Review: Groundwater management practices, challenges, and innovations in the High Plains aquifer, USA-lessons and recommended actions. Hydrogeol. J. 2010, 18, 559-575. [CrossRef]

12. Thomas, B.F.; Famiglietti, J.S. Sustainable Groundwater Management in the Arid Southwestern US: Coachella Valley, California. Water Resour. Manag. 2015, 29, 4411-4426. [CrossRef]

13. Klein, W.A.; Manda, A.K.; Griffin, M. Refining management strategies for groundwater resources. Hydrogeol. J. 2014, 22, 1727-1730. [CrossRef]

14. Bhatti, M.T.; Anwar, A.A.; Aslam, M. Groundwater monitoring and management: Status and options in Pakistan. Comput. Electron. Agric. 2017, 135, 143-153. [CrossRef]

15. Lewis, J.; Sjöström, J.; Höök, M.; Sundström, B. The Swedish model for groundwater policy: Legal foundations, decision-making and practical application. Hydrogeol. J. 2013, 21, 751-760. [CrossRef]

16. Lijzen, J.P.; Otte, P.; van Dreumel, M. Towards sustainable management of groundwater: Policy developments in The Netherlands. Sci. Total Environ. 2014, 485-486, 804-809. [CrossRef] [PubMed]

17. Jørgensen, L.F.; Villholth, K.G.; Refsgaard, J.C. Groundwater management and protection in Denmark: A review of pre-conditions advances and challenges. Int. J. Water Res. Dev. 2017, 33, 868-889. [CrossRef]

18. Guilfoos, T.; Khanna, N.; Peterson, J.M. Efficiency of viable groundwater management policies. Land Econ. 2016, 92, 618-640. [CrossRef]

19. Lowry, T.S.; Bright, J.C.; Close, M.E.; Robb, C.A.; White, P.A.; Cameron, S.G. management gaps analysis: A case study of groundwater resource management in New Zealand. Int. J. Water Res. Dev. 2003, 19, 579-592. [CrossRef]

20. Varady, R.G.; van Weert, F.; Megdal, S.B.; Gerlak, A.; Iskandar, C.A.; House-Peters, L. Groundwater policy and governance. In GEF-FAO Groundwater Governance Project-A Global Framework for Country Action; Thematic Paper No. 5; FAO: Rome, Italy, 2013.

21. Foster, S.; van der Gun, J. Groundwater governance: Key challenges in applying the global framework for action. Hydrogeol. J. 2016, 24, 749-752. [CrossRef] 
22. Food and Agriculture Organization (FAO). Shared global vision for Groundwater Governance 2030 and a call-for-action (revised edition). In GEF-FAO Groundwater Governance Project-A Global Framework for Country Action; FAO: Rome, Italy, 2015.

23. Food and Agriculture Organization (FAO). Global Diagnostic on Groundwater Governance. In GEF-FAO Groundwater Governance Project-A Global Framework for Country Action; Thematic Paper; FAO: Rome, Italy, 2016.

24. Chaisemartin, M.; Varady, R.G.; Megdal, S.-B.; Conti, K.I.; Van der Gun, J.; Merla, A.; Nijsten, G.-J.; Scheibler, F. Addressing the Groundwater Governance Challenge. A call from the "Groundwater Governance: A Global Framework for Action" Project. In Freshwater Governance for the 21st Century; Global Issues in Water Policy 6; Karar, E., Ed.; Springer International Publishing: Cham, Switzerland, 2017; pp. $205-227$. ISBN 978-3-319-43348-6.

25. Mukherji, A.; Shah, T. Groundwater socio-ecology and governance: A review of institutions and policies in selected countries. Hydrogeol. J. 2005, 13, 328-334. [CrossRef]

26. Pietersen, K.; Beekman, H.E.; Holland, M.; Adams, S. Groundwater governance in South Africa: A status assessment. Water SA 2012, 38, 453-459. [CrossRef]

27. Tanaka, T. Groundwater governance in Asia: Present state and barriers to implementation of good governance. Proc. IAHS. 2014, 364, 470-474. [CrossRef]

28. Pavelic, P.; Xayviliya, O.; Ongkeo, O. Pathways for effective groundwater governance in the least-developed-country contexto of the Lao PDR. Water Int. 2014, 39, 469-485. [CrossRef]

29. Cruz, J.V.; Coutinho, R. Breve nota sobre a importância dos recursos hídricos subterrâneos no arquipélago dos Açores. Açoreana 1998, 8, 591-594, (In Portuguese with English Abstract).

30. AHA-DRA. Plano de Gestão da Região Hidrográfica dos Açores-RH9; Versão para Consulta Pública; AHA-SRAM: Ponta Delgada, Portugal, 2015. (In Portuguese)

31. World Bank. Managing Development-The Governance Dimension; World Bank: Washington, DC, USA, 1991.

32. Cruz, J.V.; Melo, C.; Medeiros, D.; Costa, S.; Cymbron, R.; Rocha, S.; Medeiros, C.; Valente, C.; Mendes, S.; Silva, D.; et al. Water management and planning in a small island archipelago: The Azores case study (Portugal) in the context of the Water Framework Directive. Water Policy 2017, 19, 1097-1118. [CrossRef]

33. Foster, S.; Sage, R. Groundwater science in water-utility operations: Global reflections on current status and future needs. Hydrogeol. J. 2017, 25, 1233-1236. [CrossRef]

34. Serviço Regional de Estatística dos Açores (SREA). Anuário Estatístico da Região Autónoma dos Açores—Statistical Yearbook of the Azores Region 2016; SREA: Angra do Heroísmo, Portugal, 2017.

35. Cruz, J.V.; Coutinho, P.A.R.; Fontiela, J.; Freire, P. Carta de Ocupação do solo da Região Autónoma dos Açores; DROTRH: Ponta Delgada, Portugal, 2007. (In Portuguese)

36. Pacheco, J.M.; Ferreira, T.; Queiroz, G.; Wallenstein, N.; Coutinho, R.; Cruz, J.V.; Pimentel, A.; Silva, R.; Gaspar, J.L.; Goulart, C. Notas sobre a geologia do arquipélago dos Açores. In Geologia de Portugal; Dias, R., Araújo, A., Terrinha, P., Kullberg, J.C., Eds.; Escolar Editora: Lisboa, Portugal, 2013; pp. 595-690. (In Portuguese)

37. Gaspar, J.L.; Queiroz, G.; Pacheco, J.M.; Ferreira, T.; Wallenstein, N.; Almeida, M.H.; Coutinho, R. Basaltic lava balloons produced during the 1998-2001 Serreta submarine ridge eruption (Azores). In Explosive Subaqueous Volcanism; White, J.D.L., Smellie, J.L., Clague, D.A., Eds.; Geophysical Monograph 140; American Geophysical Union: Washington, DC, USA, 2003; pp. 205-212.

38. Gaspar, J.L.; Queiroz, G.; Ferreira, T.; Medeiros, A.R.; Goulart, C.; Medeiros, J. Earthquakes and volcanic eruptions in the Azores region: Geodynamic implications from major historical events and instrumental seismicity. In Volcanic Geology of São Miguel Island (Azores Archipelago); Gaspar, J.L., Guest, J.E., Duncan, A.M., Barriga, F.J.A.S., Chester, D.K., Eds.; The Geological Society Memoirs; Geological Society: London, UK, 2015; Volume 44, pp. 33-49.

39. Abdel-Monen, A.; Fernandez, L.; Boone, G. K/Ar ages from the eastern Azores group (Santa Maria, São Miguel and the Formigas Islands). Lithos 1975, 4, 247-254. [CrossRef]

40. Chovelon, P. Évolution Volcanotectonique des Iles de Faial et de Pico, Archipel des Açores-Atlantique Nord. Ph.D. Thesis, Université Paris-Sud, Paris, France, 1982.

41. Nunes, J.C. A Actividade Vulcânica na Ilha do Pico do Plistocénico Superior ao Holocénico: Mecanismo Eruptivo e Hazard Vulcânico. Ph.D. Thesis, University of the Azores, Ponta Delgada, Portugal, 1999. (In Portuguese with English Abstract). 
42. França, Z. Origem e Evolução Petrológica e Geoquímica do Vulcanismo da Ilha do Pico. Ph.D. Thesis, University of the Azores, Ponta Delgada, Portugal, 2000. (In Portuguese with English Abstract).

43. Mourisseau, M. Les Eruptions hydromagmatiques et les Xenolites Associes: Signification Geothermique. Exemples de Flores et de Faial (Açores). Ph.D. Thesis, Université de Paris XI, Orsay, France, 1987.

44. Gaspar, J.L. Ilha Graciosa (Açores). História Vulcanológica e Avaliação do Hazard. Ph.D. Thesis, University of the Azores, Ponta Delgada, Portugal, 1996. (In Portuguese with English Abstract).

45. Azevedo, J.M. Geologia e Hidrogeologia da Ilha das Flores (Açores-Portugal). Ph.D. Thesis, University of Coimbra, Coimbra, Portugal, 1998.

46. Cole, P.D.; Guest, J.E.; Queiroz, G.; Wallenstein, N.; Duncan, A.M.; Pacheco, J.; Gaspar, J.L.; Ferreira, T. Styles of Volcanism and Volcanic Hazards on Furnas Volcano, São Miguel, Azores. J. Volcanol. Geotherm. Res. 1999, 92, 39-54. [CrossRef]

47. Guest, J.E.; Gaspar, J.L.; Cole, P.; Queiroz, G.; Duncan, A.M.; Wallenstein, N.; Ferreira, T.; Pacheco, J.M. Volcanic Geology of Furnas Volcano, São Miguel, Açores. J. Volcanol. Geotherm. Res. 1999, 92, 1-29. [CrossRef]

48. Queiroz, G.; Pacheco, J.M.; Gaspar, J.L.; Aspinall, W.P.; Guest, J.E.; Ferreira, T. The last 5000 years of activity at Sete Cidades volcano (São Miguel Island, Azores): Implications for hazard assessment. J. Volcanol. Geotherm. Res. 2008, 178, 562-573. [CrossRef]

49. Larrea, P. The Magmatic Evolution of Graciosa and Corvo Oceanic Islands (Azores Archipelago). Ph.D. Thesis, University of Zaragoza, Zaragoza, Spain, 2014.

50. Pimentel, A. Pyroclastic Density Current-Forming Eruptions on Faial and Terceira islands, Azores. Ph.D. Thesis, University of the Azores, Ponta Delgada, Portugal, 2015.

51. DROTRH/INAG. Plano Regional da Água; Relatório Técnico; DROTRH-INAG: Ponta Delgada, Portugal, 2001. (In Portuguese)

52. Cruz, J.V.; Pacheco, D.; Coutinho, R.; Cymbron, R.; Mendes, S.; Antunes, P.; Fontiela, J.; Freire, P. Chemical monitoring of river water bodies in an EU outermost region: Examples from the Azores archipelago (Portugal). J. Environ. Monit. 2010, 12, 2216-2225. [CrossRef] [PubMed]

53. Cruz, J.V.; Pacheco, D.; Porteiro, J.; Cymbron, R.; Mendes, S.; Malcata, A.; Andrade, C. Sete Cidades and Furnas lake eutrophication (São Miguel, Azores): Analysis of long-term monitoring data and remediation measures. Sci. Total Environ. 2015, 520, 168-186. [CrossRef] [PubMed]

54. Pacheco, D.; Malcata, A.; Mendes, S.; Cruz, J.V.; Gaspar, J.L. Monitorização da Qualidade da Água das Lagoas de São Miguel; Comparação de Resultados entre 2004 e 2008; SRAM: Ponta Delgada, Portugal, 2010. (In Portuguese)

55. Andrade, C.; Viveiros, F.; Cruz, J.V.; Coutinho, R.; Silva, C. Estimation of the $\mathrm{CO}_{2}$ flux from Furnas volcanic lake (São Miguel, Azores). J. Volcanol. Geotherm. Res. 2016, 315, 51-64. [CrossRef]

56. DROTRH. Relatório Síntese de Caracterização da Região Hidrográfica, Arquipélago dos Açores, Portugal; DROTRH: Ponta Delgada, Portugal, 2006. (In Portuguese)

57. Conference of European Church (CEC). Guidance No. 2-Identification of Wáter Bodies. Commmon Implementation Stategy for the Water-Framework Directive; (2000/60/EC); CEC: Luxembourg, 2003.

58. Cruz, J.V. Ensaio Sobre a Água Subterrânea nos Açores. História, Ocorrência e Qualidade; SRA: Ponta Delgada, Portugal, 2004. (In Portuguese)

59. Cruz, J.V.; Coutinho, R.; Pacheco, D.; Cymbron, R.; Antunes, P.; Freire, P.; Mendes, S. Groundwater salinization in the Azores archipelago (Portugal). Environ. Earth Sci. 2011, 62, 1273-1285. [CrossRef]

60. Cruz, J.V.; Andrade, C. Groundwater salinization in Graciosa and Pico islands (Azores archipelago, Portugal): Processes and impacts. J. Hydrol. Reg. Stud. 2017, 12, 69-87. [CrossRef]

61. Paradela, P.L. Hidrogeologia geral das ilhas adjacentes. Comun. Serv. Geol. Port. 1980, 66, $241-256$. (In Portuguese)

62. Cruz, J.V.; Pacheco, D.; Cymbron, R.; Mendes, S. Monitoring of the groundwater chemical status in the Azores archipelago (Portugal) in the context of the EU Water Framework Directive. Environ. Earth Sci. 2010, 61, 173-186. [CrossRef]

63. Cruz, J.V.; Silva, M.O.; Dias, M.I.; Prudêncio, M.I. Groundwater composition and pollution due to agricultural practices at Sete Cidades volcano (Azores, Portugal). Appl. Geochem. 2013, 29, 162-173. [CrossRef]

64. Cruz, J.V.; Andrade, C.; Pacheco, D.; Mendes, S.; Cymbron, R. Nitrates in Groundwater Discharges from the Azores Archipelago: Occurrence and Fluxes to Coastal Waters. Water 2017, 9, 125. [CrossRef] 
65. Cordeiro, S.; Coutinho, R.; Cruz, J.V. Fluoride content in drinking water supply in São Miguel volcanic island (Azores, Portugal). Sci. Total Environ. 2012, 432, 23-36. [CrossRef] [PubMed]

66. Costa, S. Avaliação de Fluoretos na Água de Consumo do Concelho da Praia da Vitória (ilha Terceira, Açores) e suas Consequências a Nível da Saúde Pública. Master's Thesis, University of the Azores, Angra do Heroísmo, Portugal, 2013.

67. Cruz, J.V.; Freire, P.; Costa, A. Mineral waters characterization in the Azores archipelago (Portugal). J. Volcanol. Geotherm. Res. 2010, 190, 353-364. [CrossRef]

68. Freire, P.; Andrade, C.; Viveiros, F.; Silva, C.; Coutinho, R.; Cruz, J.V. Mineral water occurrence and geochemistry in the Azores volcanic archipelago (Portugal): Insight from an extended database on water chemistry. Environ. Earth Sci. 2015, 73, 2749-2762. [CrossRef]

69. Cruz, J.V.; Fontiela, J.; Prada, S.; Andrade, C. The chemical status of groundwater and pollution risk in the Azores archipelago (Portugal). Environ. Earth Sci. 2015, 73, 2763-2777. [CrossRef]

70. Aller, L.; Bennett, T.; Lehr, J.H.; Perry, R.; Hackett, G. DRASTIC. A Standardized System for Evaluating Ground Water Pollution Potential Using Hydrogeologic Settings; EPA: Ada, OK, USA, 1987.

71. Cymbron, R.; Pacheco, D.; Gonçalves, V.; Cabral, M.; Cruz, J.V.; Raposeiro, P.; Costa, A.; Marques, H.; Domingos, M.; Nunes, J.C.; et al. Monitorização da qualidade das águas interiores das ilhas de Santa Maria e São Miguel da Região Autónoma dos Açores. In Técnicas y Métodos para la Gestión Sostenible Del agua en la Macaronesia; Ortega, A., Peña, L., Rodriguez, G., Eds.; ITC: Tenerife, Spain, 2005; pp. 295-334. (In Portuguese)

72. Cymbron, R.; Pacheco, D.; Cabral, M.; Cruz, J.V.; Domingos, M.; Nunes, J.C.; Coutinho, R. Monitorização da qualidade das águas subterrâneas das ilhas de Santa Maria e São Miguel da Região Autónoma dos Açores. In Proceedings of the 8th Congresso da Água, Figueira da Foz, Portugal, 13-17 March 2006. (In Portuguese)

73. Grath, J.; Scheidleder, A.; Uhlig, S.; Weber, K.; Kralik, M.; Keimel, T.; Gruber, D. The EU Water Framework Directive: Statistical Aspects of the Identification of Groundwater Pollution Trends and Aggregation of Monitoring Results; Final Report; Austrian Federal Ministry of Agriculture and Forestry, Environment and Water Management: Wien, Austria, 2001.

74. Mechlem, K. Groundwater governance: The role of legal frameworks at the local and national level-Established practice and emerging trends. Water 2016, 8, 347. [CrossRef]

75. Cruz, J.V.; Pacheco, D.; Costa, S.; Melo, C.; Cymbron, R.; Nogueira, R.; Brito, A.G. Implementation of the Water Framework Directive in an outermost EU region: The case of Azores archipelago (Portugal). Open Hydrol. J. 2012, 6, 1-14. [CrossRef]

76. Mendes, S.; Pacheco, D.; Cruz, J.V. O SIG na implementação de medidas de proteção das águas subterrâneas na Rergião Autónoma dos Açores. In Proceedings of the 10th Congresso da Água, Alvor, Portugal, 22-24 March 2010. (In Portuguese)

77. Mendes, S.; Pacheco, D.; Coutinho, R.; Antunes, P.; Cruz, J.V.; Gaspar, J.L. Proteção de origens de água subterrânea na Região Autónoma dos Açores. In Proceedings of the 10th Congresso da Água, Alvor, Portugal, 22-24 March 2010. (In Portuguese)

78. AHA-DRA. Plano de Gestão da Região Hidrográfica dos Açores—RH9; Versão para Consulta Pública; AHA-SRAM: Ponta Delgada, Portugal, 2011. (In Portuguese)

79. Lopéz-Vera, F. Groundwater: Na invisible resource. Int. J. Water Res. Dev. 2012, 28, 141-150. [CrossRef]

80. World Bank. Problem-Driven Governance and Political Economy Analysis: A Good Practice Framework; The World Bank: Washington, DC, USA, 2010.

81. Van der Gun, J. Sharing groundwater information. Knowledge and experience on a worldwide scale. In The Agricultural Ground Water Revolution: Opportunities and Threats to Development; Giordano, M., Villholth, K., Eds.; CABI, International Water Management Institute: Wallingford, UK, 2007; pp. 362-392.

82. Van Steenberger, F. Promoting local management in groundwater. Hydrogeol. J. 2006, 14, 380-391. [CrossRef]

83. Theesfeld, I. Institutional challenges for national groundwater governance: Policies and issues. Groundwater 2010, 48, 131-142. [CrossRef] [PubMed]

84. Jarvis, T. Strategies for ground water resources conflict resolution and management. In Overexploitation and Contamination of Shared Ground Water Resources: Management, (Bio) Technological, and Political Approaches to Avoid Conflicts; Darnault, C.J.G., Ed.; Springer: Dordrecht, The Netherlands, 2006; pp. 393-414.

85. Mechlem, K. Groundwater policy and governance. In GEF-FAO Groundwater Governance Project-A Global Framework for Country Action; Thematic Paper No. 6; FAO: Rome, Italy, 2012. 
86. Ozerol, G.; Newig, J. Evaluating the success of public participation in water resources management: Five key constituents. Water Policy 2008, 10, 639-665.

87. Conference of European Church (CEC). Report on the implementation of the Water Framework Directive River Basin Management Plans; (Member State: PORTUGAL) Accompanying Communication from the Commission to the European Parliament and the 664 Council on The Water Framework Directive and the Floods Directive; COM (2015) 120665 Final; Issued in 9th March; CEC: Brussels, Belgium, 2015. 